\title{
Dibujando la nación desdibujando al enemigo. Imágenes de movilización bélica en la prensa de guerra paraguaya, 1867-1868
}

\author{
por María Lucrecia Johansson
}

Abstract. - Between 1864 and 1870, the Paraguayan forces clashed with the armies of Argentina, Brazil and Uruguay, in what was called the War of the Triple Alliance (1864-1870). During that war, the Paraguayan government revolutionized journalism by the creation of two illustrated newspapers: El Centinela and Cabichuí (1867-1868). The engravings of these newspapers created a system of opposition we/they, characterized by the contrast between negative and positive images. The aim of this paper is to analyse how the press built negative images of the enemy and how those images were the basis for creating a positive representation of Paraguay.

\section{La prensa de guerra paraguaya}

En la segunda mitad del siglo XIX, Paraguay se convirtió en escenario de la contienda más sangrienta de América del Sur. Por más de cinco años las fuerzas paraguayas, comandadas por el mariscal Francisco Solano López, se enfrentaron con los ejércitos de la Triple Alianza formada por la República Argentina, el Imperio del Brasil y la República Oriental del Uruguay, en la que se denominó guerra del Paraguay o guerra de la Triple Alianza (1864-1870).

Durante la primera fase de la contienda (diciembre de 1864 y principios de 1866) el enfrentamiento se desenvolvió en parte fuera de las fronteras de Paraguay. En la provincia argentina de Corrientes la lucha se extendió hasta que la victoria de los ejércitos aliados hizo replegar a las tropas paraguayas a su territorio. En la segunda fase de la contienda (desde 1866 hasta 1869), el enfrentamiento se convirtió en una guerra de trincheras o de desgaste, solo alterada por grandes batallas con miles de muertos que no lograban modificar las líneas de combate. En la última fase de la guerra (1869 hasta marzo de 1870), los ejércitos aliados lograron sus objetivos: se apoderaron 
de la fortaleza de Humaitá y de la capital de Paraguay, instalaron un gobierno títere en Asunción y coronaron su victoria con la muerte del presidente de Paraguay, el mariscal López.

Desde el comienzo de las hostilidades, la prensa de los países beligerantes se dedicó a tratar ampliamente el conflicto. En el caso del Paraguay, inmerso en un contexto de guerra total ${ }^{1}$, el gobierno inició una campaña de propaganda que consistió en la difusión de ideas tendientes a inducir determinados comportamientos ${ }^{2}$. No es de extrañar que durante la guerra de la Triple Alianza los gobiernos contendientes utilizaran a la prensa con fines propagandísticos ya que, como bien sostiene Jean-Marie Domenach, a partir del siglo XVIII la propaganda se convirtió en un auxiliar de las estrategias de guerra, que comenzaron a conducirse tanto por las armas como por la ideología ${ }^{3}$.

Las autoridades de los países implicados en el conflicto otorgaron una particular importancia a los periódicos porque entendieron que a través de ellos podrían regular las conductas y modelar las representaciones, en un contexto en el que eran impostergables las necesidades de movilizar moralmente a la población y de garantizar la defensa de la identidad en peligro. Esas nuevas representaciones se difundieron con el fin de crear al menos dos efectos: por un lado, afianzar la cohesión social, mediante la reducción, y más aún de la eliminación de las diferencias políticas e ideológicas y la consolidación de vínculos fundados en lo emocional, y por otro, imponer imágenes estereotipadas y negativas del enemigo como un reflejo opuesto de una autoimagen positiva.

Para poder contar con un mayor número de órganos oficiales de difusión, el gobierno paraguayo creó entre abril de 1867 y febrero de 1869 cuatro periódicos: El Centinela (1867-1868), Cabichuí (1867-1868), Cacique Lambaré (1867-1868) y Estrella (1869). A lo largo del conflicto llegaron a publicarse cinco periódicos, incluyendo a El Semanario de Avisos y Conocimientos Útiles (1853-1869) que venía editándose con anterioridad al enfrentamiento.

El primer objetivo de esa nueva prensa fue ampliar el número de lectores, razón por la cual esos periódicos transformaron su forma y su contenido con base en una serie de expectativas atribuidas al nuevo público al que

1 Luc Capdevila, Una guerra total. Paraguay, 1864-1870. Ensayo de historia del tiempo presente (Buenos Aires 2010).

2 Ingrid Schulze Schneider, El poder de la propaganda en las guerras del siglo XIX (Madrid 2001). Alejandro Pizarroso Quintero, "Historia de la propaganda: Una aproximación metodológica”: Historia y comunicación 4 (1999), p. 145-171.

3 Jean-Marie Domenach, La propaganda politica (Buenos Aires 1968). 
estaban dirigidos, integrado especialmente por los hombres movilizados para el combate. Al mismo tiempo, una nueva práctica de lectura que se desarrollaba en el ámbito público, en grupo y en voz alta, sobre todo - aunque no exclusivamente - en las trincheras, se impuso con el fin de garantizar la difusión del mensaje propagandístico. Algunos de los rasgos más novedosos y significativos que presentaron esas publicaciones fueron el uso del guaraní, lengua que hablaba la mayor parte de la población, y la incorporación de ilustraciones en El Centinela y Cabichuí, periódicos que a través de sus xilograbados buscaron facilitar la captación del mensaje a los que no sabían leer. ${ }^{4}$ Las páginas de esos periódicos de guerra se cargaron de imágenes portadoras de fuertes significaciones simbólicas, que a través de su estereotipación fueron validadas como instrumentos de defensa nacional.

Poniendo el foco en el discurso de movilización difundido a través de los grabados, el objetivo del presente trabajo es analizar cómo la propaganda de guerra fue estructurando un sistema de oposición nosotros/ellos, que reposaba sobre una construcción binaria que presentaba, alternadamente, parejas asimétricas: civilización/barbarie, república de ciudadanos/ imperio servil, hombres libres/esclavos, corajudos/cobardes, cristianos/ moros, blancos/negros, humano/animal, etc.

Esa oposición nosotros/ellos se plasmó a través del contraste entre imágenes utilizadas de dos maneras: por un lado, se usó una imagen negativa del adversario para revelar una autoimagen positiva, construyendo desde los trazos oprobiosos con que definían al adversario el retrato espléndido de los paraguayos. Así, a la vez que se trataba de predisponerlos, convenciéndolos del carácter abominable del oponente y de su causa, se buscaba despertarles el sentido de unidad y compromiso con la lucha exaltando la benevolencia del propio carácter. En El Centinela y en Cabichuí, las operaciones básicas de atribución de rasgos negativos al enemigo fueron: la demonización, la animalización y la apelación a rasgos étnicos. La segunda manera de plasmar la oposición de imágenes estereotipadas fue realizar el procedimiento contrario, es decir, presentar de forma positiva, idealizada, al Paraguay y a sus soldados y ciudadanos, para revelar en negativo un perfil de los adversarios. Otras estrategias gráficas utilizadas por los grabadores para

4 Para un análisis más amplio de la prensa de guerra paraguaya consultar: María Lucrecia Johansson, Soldados de papel. La propaganda en la prensa paraguaya durante la guerra de la Triple Alianza (1864-1870) (Cádiz 2014). Otros aportes muy interesantes al tema están en: Michael Kenneth Huner, "Cantando la república. La movilización escrita del lenguaje popular en las trincheras del Paraguay, 1867-1868": Páginas de Guarda (2007), p. 115-134. Thomas Whigham, "Building the Nation While Destroying the Land. Paraguayan Journalism during the Triple Alliance War, 1864-1870": Jahrbuch für Geschichte Lateinamerikas 49 (2012), p. 157-180. 
plasmar el sistema de oposición nosotros/ellos se basaron en el establecimiento de contrastes dados por el color, claro/oscuro, el tamaño, grande/ pequeño, lo estético, hermoso/feo, etc.

\section{Soldados artistas}

Los periódicos El Centinela y Cabichuí exhibieron distintos estilos en sus grabados, lo que, como las mismas publicaciones señalaron, se relacionaba con la formación de sus artistas y con el lugar de publicación. Frente a esas diferencias formales presentaron criterios comunes sobre la función de las imágenes y compartieron apreciaciones sobre el alto valor artístico y comunicacional que las caracterizaba. Cabichuí, por ejemplo, se manifestó orgulloso por el nivel de sus xilografías que "se trabajan con el fusil en una mano y el buril en otra, puesto que estamos frente a frente, a un palmo de distancia de nuestros feroces enemigos". ${ }^{5}$

El Centinela, por su parte, refiriéndose a la labor de Cabichuí, definió a sus caricaturas como "ingeniosas y muy de circunstancias", y se lamentó afirmando: "nosotros, aunque con un artista de profesión, no podemos alcanzar esa expresión que sabe dar a sus grabados el mismo soldado que ve, siente y palpa los acontecimientos". ${ }^{6}$ Las caricaturas y escenas de la guerra que podemos ver en sus páginas contaron con los aportes del artista y arquitecto italiano Alessandro Ravizza, que se ocupaba de realizar los dibujos. Los encargados de trabajar la madera eran sus colaboradores paraguayos Juan José Benítez y Manuel L. Colunga, quien firmó once de las cuarenta y nueve ilustraciones publicadas. Mientras que Ravizza era estimado como un artista de profesión, sus colaboradores eran considerados meros aficionados. Este hecho llevó al periódico a valorar de manera especial el trabajo de sus cinceladores, acerca de los que escribió: esos artistas que por "primera vez toman el buril" ostentan la particularidad de ser "guerreros artistas (...) esos que vencen toda dificultad". ${ }^{7}$ En el mismo artículo destacó que una de las tallas había sido realizada por "uno de los heridos del Batallón $\mathrm{n}^{\mathrm{0}}$. 12, que aún tiene la bala en el cuerpo". ${ }^{8}$ De acuerdo a José Antonio Vázquez, quien llevaba alojada la bala era el ya mencionado Benítez. ${ }^{9}$

5 Cabichuí, n4, 23/04/1867, pp. 3-4.

6 El Centinela, ${ }^{\circ} 7,06 / 06 / 1867$, p. 2.

7 El Centinela, $\mathrm{n}^{\circ} 2,02 / 05 / 1867$, p. 4.

8 El Centinela, $\mathrm{n}^{\circ} 2,02 / 05 / 1867, \mathrm{p} .4$.

9 José Antonio Vázquez, El Centinela. Colección del semanario de los paraguayos en la guerra de la Triple Alianza. 1867 (Buenos Aires 1964), p. 5. 
Cabichuí, como lo deja entrever la cita de El Centinela, solo contó con colaboradores sin formación académica. El hecho de que sus grabados fueran "elaborados sin dirección de ningún artista profesional" fue destacado por el periódico, que se enorgullecía de esta meritoria circunstancia y la presentaba como la razón de la trascendencia que alcanzaban sus ilustraciones. ${ }^{10}$ Los encargados de elaborar esas obras fueron:

"el joven militar Fulgencio Godoy, que acompañado de sus camaradas, el sargento Manuel Perina, el cabo Francisco Belazco y los soldados Juan Bargas, Inocencio Aquino y Genaro Cáceres, produce nuestros grabados".

Cabichuí consideraba que "nadie ignoraba" que sus grabados eran "los primeros de este género de obras en nuestro campo" y tanto fue el valor que otorgó a las imágenes que llegó incluso a afirmar que cuando "la lengua no es bastante, la pluma es insuficiente, el papel escasea, venga, pues, la madera, tómese el lápiz, corra el buril, y hable la creación entera". ${ }^{12}$

\section{Dibujando al enemigo}

Concebida como una aberración absolutamente ajena al mundo terrenal, la Triple Alianza fue simbolizada, tanto en las expresiones gráficas como verbales de la prensa de guerra paraguaya, a través de entes demoníacos o monstruos. El Centinela nos da una clara muestra de esas identificaciones: "Hoy en el siglo de las luces, y cuando las ideas supersticiosas no tienen cabida, reaparecen las arpías". ${ }^{13}$ La misma evidencia ofrecen sus grabados. En una de sus representaciones aparece una serpiente de tres cabezas que es vencida por tres soldados paraguayos que, montados arriba de su cuerpo, han logrado separar dos de sus cabezas, mientras la tercera, que se encuentra amarrada por una cuerda, está pronta a caer.

${ }^{10}$ Cabichui, n ${ }^{\circ}$, 23/05/1867, p. 4.

${ }^{11}$ Cabichuí, n ${ }^{\circ}, 23 / 05 / 1867$, p. 4.

${ }^{12}$ Cabichuí, n ${ }^{\circ}, 27 / 05 / 1867$, p. 4.

${ }^{13}$ El Centinela, nº3, 09/05/1867, p. 2. 


\section{Imagen 1:"La ex-triple alianza y sus vencedores"}

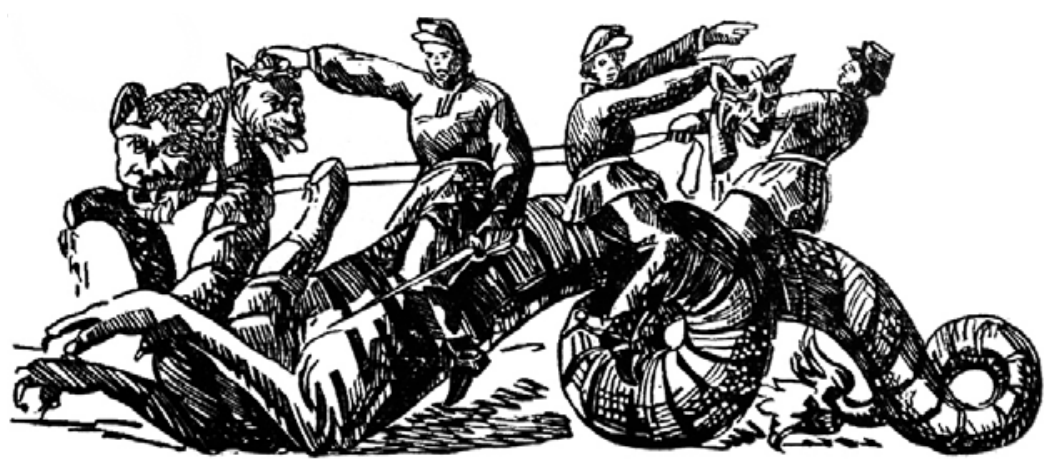

Fuente: El Centinela, n³, 09/05/1867, p. 1.

A través de las imágenes de la Triple Alianza como un monstruo aterrador y maligno se buscaba, no incitar miedo, sino odio hacia los enemigos. El grabado responde perfectamente a ese propósito: solo bastan tres soldados paraguayos para destruir al inmenso y horrible engendro. Por otra parte, el contraste de escala resalta la grandeza de esos soldados que, erguidos en el centro de la imagen, luchan juntos para destruir a quien los amenaza. De esta manera, lo que se pretendió significar fue que la valentía de los soldados paraguayos no se detenía ni siquiera ante la ferocidad no natural de un monstruo de tres cabezas.

Junto a las representaciones malévolas del enemigo, la prensa de guerra abundó en el uso de términos destinados a subrayar el carácter satánico que les atribuían a los aliados. Así, por ejemplo, se llama "Cachidiablo" al comandante brasileño marqués de Caxias o se exhorta a los soldados paraguayos a luchar en contra de "todos los demonios en figura de negros". ${ }^{14}$ Inclusive El Centinela, luego de explicar que "los negros y los no negros que mueren en el ejército invasor se van casaca y todo al infierno" 15 , le aconseja al diablo utilizar a los primeros como carbón, "ya que de soldados han probado tan mal". ${ }^{16}$ Asimismo, son abundantes las representaciones del demonio esperando impaciente la muerte de los soldados aliados - quienes según Cabichui "no tienen religión alguna sino la del crimen"17 -, para llevarlos consigo o dándoles la bienvenida al infierno.

\footnotetext{
${ }^{14}$ El Centinela, $\mathrm{n}^{\circ} 22,19 / 09 / 1867$, p. 4.

${ }^{15}$ El Centinela, $\mathrm{n}^{\circ} 2,02 / 05 / 1867$, p. 3.

${ }^{16}$ El Centinela, $\mathrm{n}^{\circ} 2,02 / 05 / 1867$, p. 3.

${ }^{17}$ Cabichuí, n91, 26/06/1868, p. 3.
} 
Las representaciones demoníacas se inscriben dentro de la herencia guaraní, cuyos diablos de forma zoomórfica, como señala Josefina Plá, simbolizaban más bien a seres en desgracia que a entes terroríficos..$^{18}$ En un grabado del periódico El Centinela se ve una torre de vigilancia - mangrullo -, desde la que un soldado paraguayo amenaza con un látigo - elemento simbólico de la condición de esclavos que la prensa de guerra atribuía a los reclutas brasileños - a las tropas aliadas, que comienzan a huir despavoridas impulsadas por su temor al instrumento de castigo que se exhibe. Entre los soldados que huyen aparece un monstruo cubierto de pelos, con cuernos en la cabeza y con una larga cola entre las piernas. Lo más interesante es el epígrafe que acompaña al grabado: "Estoy exorcizando negros desde este púlpito paraguayo". La identificación del mangrullo con el púlpito y del centinela con un sacerdote pone en evidencia otro par de conceptos en oposición: cristianos-moros, provenientes del legado español, que justipreciaron los paraguayos en la prensa de guerra. Por medio del contraste de escalas, que muestra al soldado en lo alto y abajo a unos pequeños enemigos, se simboliza la superioridad moral de los paraguayos.

\section{Imagen 2:"Estoy exorcizando negros desde este púlpito paraguayo, y el aspergeo tiene a los muleques con el rabo gateando"}

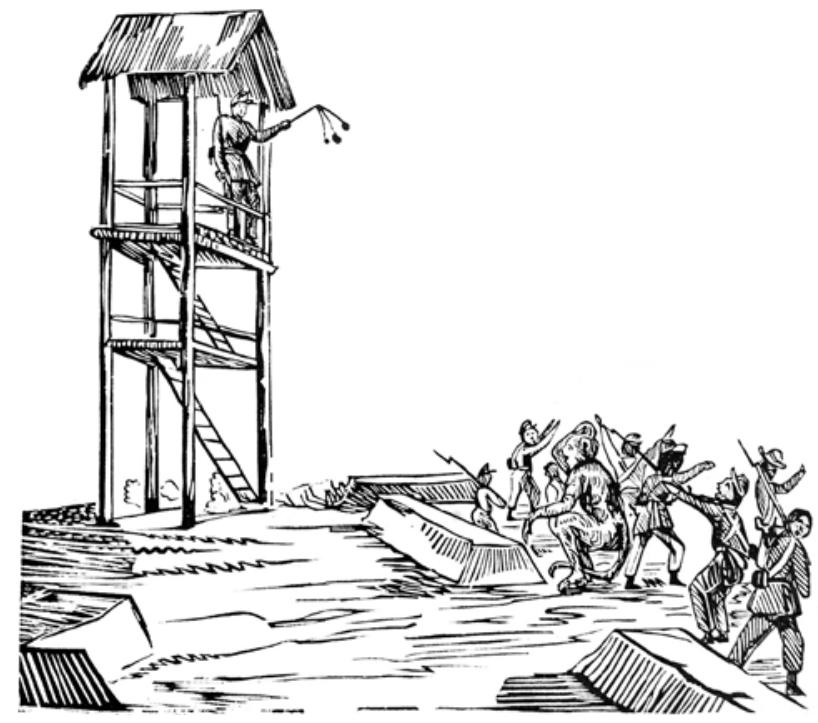

Fuente: El Centinela, $n^{\circ} 6,30 / 05 / 1867$, p. 1.

${ }^{18}$ Josefina Plá, "El grabado. Instrumento de la defensa": Ticio Escobar/Osvaldo Salerno, Cabichuí. Periódico de la guerra de la Triple Alianza (Asunción 1984). 
En fuerte contraste con estas imágenes malévolas, ángeles y cruces fueron grabados como forma de construir una imagen positiva del Paraguay. Esta transición desde el simbolismo religioso al político fue habitual en la prensa de guerra paraguaya, donde se encuentran, por ejemplo, imágenes del "ángel de las batallas" y del "ángel tutelar". El ángel tutelar aparece representado con una espada en su mano izquierda, con la que aparta a un dragón de un nido de palomas, que simbolizan al pacífico Paraguay. El texto que corresponde a esta imagen señala que ese ángel es el protector del pueblo paraguayo, que con su espada defiende "los grandes intereses de la Patria" y protege "las vidas y las propiedades que el monstruo imperial amenaza tragar". ${ }^{19}$

Estos grabados con alegorías religiosas buscaron simbolizar el papel de lo divino en la causa paraguaya, presentando a Dios como guía del mariscal López y como protector de su pueblo. Según lo expresaba Cabichuí: "Dios ha querido ligar nuestra suerte a la de este hombre providencial"; también afirmaba que la unidad existente entre "Dios, Patria y Mariscal López" garantizaba el triunfo paraguayo. ${ }^{20} \mathrm{Al}$ recurrir a esa simbología religiosa al igual que en el caso ya mencionado de los diablos zoomórficos de la cultura guaraní -, los artistas apelaban a representaciones del universo mental de los paraguayos, por lo que esas imágenes resultaban muy potentes y fáciles de ser captadas por el público al que estaban dirigidas.

Junto a la demonización, la animalización fue otra de las estrategias gráficas utilizadas para representar a los líderes de la Triple Alianza y a los soldados enemigos. El gran zoológico que los artistas paraguayos crearon en las páginas de los periódicos se explica, por un lado, por la gran posibilidad expresiva que este recurso les ofrecía y, por otro, porque facilitaba la comunicación de los mensajes al apelar a la mitología guaraní o a locuciones coloquiales ampliamente conocidas.

El grabado que ilustra el artículo "La conferencia secreta" muestra como monos al Emperador del Brasil, al visconde de Tamandaré y al mariscal Polidoro, jefes militares del ejército enemigo. Los monos están junto a una mesa en la que descansa la corona imperial, y son presentados luciendo vestimentas militares, condecoraciones y portando armas. En el texto que acompaña el dibujo se aplica el sustantivo "monada" a las figuras representadas, significando, a través del uso irónico y enfático de la palabra, que a los paraguayos esas figuras les resultaban afectadas, enfadosas y totalmente incapaces en sus roles de conductores del ejército imperial, el cual con esos guías jamás podría "conquistar esa nación de valerosos guerreros" que era Paraguay. ${ }^{21}$

\footnotetext{
${ }^{19}$ El Centinela, $\mathrm{n}^{\circ} 25,10 / 10 / 1867$, p. 2.

${ }^{20}$ Cabichuí, no85, 13/05/1867, p. 2.

${ }^{21}$ El Centinela, no3, 09/05/1867, p. 4.
} 


\section{Imagen 3: "Toma! Y que hacen aquí esos tres? - Chit! Es el Emperador del Brasil, el Visconde de Tamandaré y el Mariscal Polidoro que están en conferencia secreta sobre la guerra del Paraguay ... ¡Monada!"}

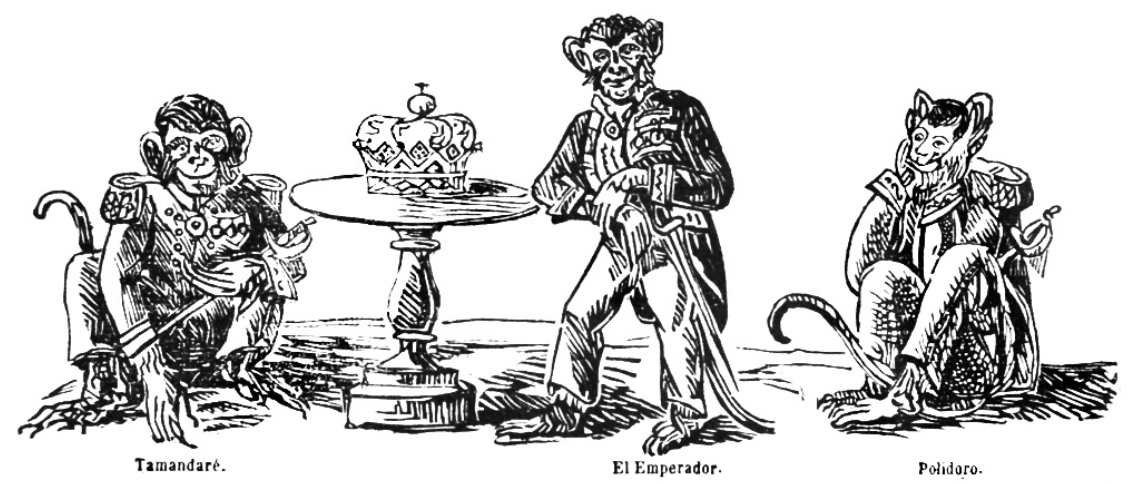

Fuente: El Centinela, n³, 09/05/1867, p. 3.

Si con la representación demonizada del enemigo se pretendió mostrar la naturaleza sobrenatural de la Triple Alianza, frente a la que el Paraguay estaba protegido por el apoyo celestial, la animalización buscó evocar su inferioridad, incapacidad y la dependencia del amo. Ante estos animales sin rasgo alguno de peligrosidad, los paraguayos aparecen representados como cazadores o domesticadores que se divierten sobremanera a expensas del enemigo. En varios grabados se representa la "caza de los negros" como una de las diversiones favoritas de los soldados paraguayos. ${ }^{22}$

La prensa de guerra también explotó el hecho de que las fuerzas imperiales estuvieran constituidas en su mayor parte por esclavos que habían sido manumitidos al ser incorporados al servicio militar ${ }^{23}$. A través de la atribución del carácter de serviles a los soldados brasileños, la prensa paraguaya plasmaba la idea de que la pugna era un enfrentamiento entre dos sistemas políticos: la república de hombres libres representada por Paraguay contra la monarquía esclavista de Brasil. ${ }^{24}$

${ }^{22}$ Cabichui, no39, 19/09/1867, p. 4.

${ }^{23}$ Francisco Doratioto, Maldita guerra. Nueva historia de la guerra del Paraguay (Buenos Aires 2008).

${ }^{24}$ María Lucrecia Johansson, "Paraguay contra el monstruo anti-republicano. El discurso eriodístico paraguayo durante la guerra de la Triple Alianza (1867-1869)": Historia Crítica 47 (2012), pp. 71-92. 
Junto a los artículos con asiduas referencias relativas a la conformación del Ejército Imperial y a sus prácticas de reclutamiento, la prensa de guerra adjudicó al enemigo brasileño disvalores como la sumisión abyecta y el miedo servil. Trabajados en esta dirección, los grabados muestran al Emperador ejerciendo control a través de cadenas y sembrando miedo a través de rebenques y látigos. Es el caso del grabado en el que Pedro II, con gesto amenazante, enseña el zurriago a un jefe militar, negro y corpulento, que prosternado ante el monarca, luce una expresión de temor.

En Cabichuí, los grabados muestran a los soldados aliados, como "bichos de tanta cobardía" 25 , huyendo despavoridos de un solo soldado paraguayo que los amenaza con un látigo. En el artículo que acompaña a uno de estos grabados se lee que "el esclavo no es más que una bestia, y una bestia estúpida", porque no ama la libertad. ${ }^{26}$ A continuación se aclara, que dado el carácter de bestias de los esclavos, con ellos solo basta el rebenque.

El carácter de esclavos de los soldados brasileños fue también resaltado con la intención de proclamar que el éxito del Paraguay sería también un triunfo para ellos, ya que los súbditos del Imperio se convertirían en ciudadanos de pleno derecho: "Los negros tendrán que agradecernos, porque al fin los haremos vivir sin argollas, sin cadenas y sin opresión". ${ }^{27}$

\section{Dibujando la nación paraguaya}

En contraste con la animalización de los enemigos cargada de connotaciones negativas, la imagen del león fue usada para representar al Paraguay. Tanto en El Centinela como en Cabichuí la figura de este emblemático animal es utilizada para simbolizar la majestuosidad y poder del ejercito paraguayo. Los artículos hacen referencias al "ejército de leones" y al "soldado león", para aludir a la bravura con la que enfrentaban al "ejército de sapos" o "ejército de macacos" de los aliados.

En muchos grabados, el león, "el rey del valor y de la fuerza", frena el avance de los jefes militares aliados representando el poderío de la inexpugnable fortaleza paraguaya de Humaitá. El gran valor simbólico otorgado al león se convierte en una imagen positiva de la acción de los paraguayos en

\footnotetext{
${ }^{25}$ Cabichuí, no $45,10 / 10 / 1867$, p. 2.

${ }^{26}$ Cabichui, no2, 16/05/1867, p. 2.

${ }^{27}$ El Centinela, $\mathrm{n}^{\circ} 1,25 / 04 / 1867$, p. 3.
} 
el campo de batalla, imagen que despierta no solo temor y respeto, sino también admiración en el enemigo. El león, plasmado como símbolo de la nación paraguaya, aparece también atacando al presidente argentino Bartolomé Mitre y a Caxias, comandante en jefe del ejército de Brasil, quienes no pueden huir porque a sus espaldas se encuentra Pedro II con un látigo, amenazándolos. El análisis de imágenes como la mencionada permite inferir que el león aparece como representación no solo de la ferocidad sino también de la unidad de todos los paraguayos en la lucha. La cobardía de los aliados está graficada por el azote que el Emperador debe usar para que sus súbditos y aliados enfrenten a ese terrible león..$^{28}$

En dos oportunidades "el indómito león paraguayo" aparece representado junto al mariscal López, con la triple intención connotativa de asimilar ambas figuras - magnificas en los valores que comparten -, de subrayar la obediencia del pueblo a su mariscal y destacar la decisión inquebrantable de los paraguayos de pelear junto a él con bravura. Al lado de su guía, el león tiene una actitud expectante, está a la espera de sus órdenes para avanzar hacia el enemigo. De esta manera, la prensa logra consustanciar a López con la poderosa fiera símbolo de supremacía, fuerza y señorío.

Es interesante subrayar el contraste de imágenes entre un Emperador que, a pesar del uso constante del látigo y de cadenas, no logra domesticar a sus súbditos "monos" ni a sus aliados "cobardes", y un Mariscal que, sin recurrir a ningún instrumento de sumisión, controla un feroz león. En el artículo que acompaña este grabado, López no es presentado como un simple domador sino como el creador de la nación paraguaya:

"El mariscal López en medio del fragor de la guerra [...] ha hecho surgir una nueva nación, que el mundo mira sorprendido [...] una nación que combatiendo por la causa del derecho y de la libertad, con una bravura y abnegación supremas, ha inclinado la cerviz de los violadores del código internacional, rodeándose de simpatías y de aplausos". ${ }^{29}$

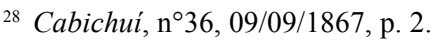

${ }^{29}$ Cabichui, n²2, 24/07/1867, p. 1.
} 


\section{Imagen 4: "El Mariscal López en San Fernando”}

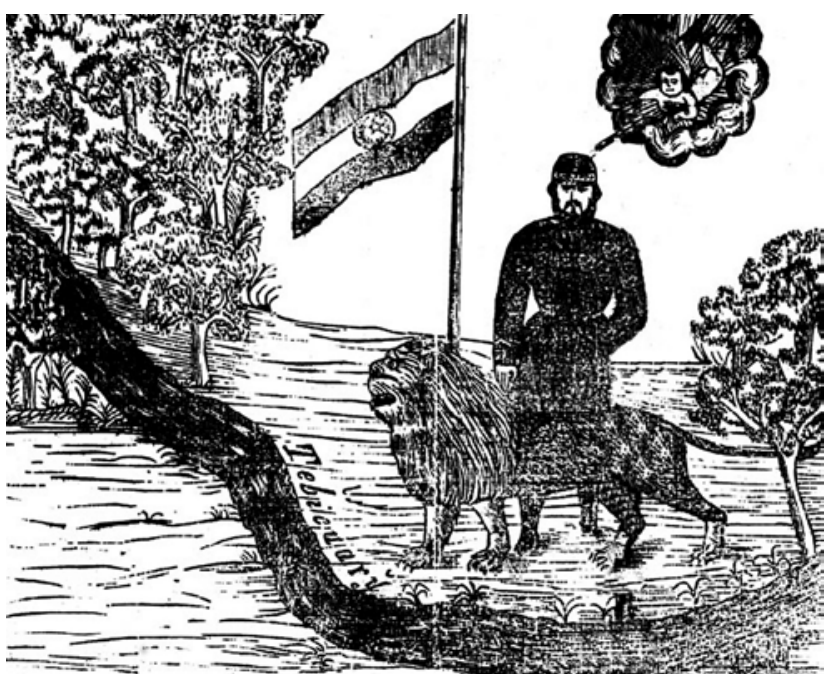

Fuente: Cabichuí, n85, 13/05/1868, pp. 2-3.

A lo largo del conflicto, los periódicos fueron cimentando en blanco y en negro las representaciones de sus principales protagonistas. Así, mientras el mariscal López era presentado como una divinidad comparable a Cristo, Pedro II era equiparado con el demonio, y Mitre y el presidente uruguayo Venancio Flores con Judas, por haber traicionado a sus países. La mitificación de López se mantuvo a pesar de las consecuencias nefastas de la conflagración; y a medida que pasaban los años y la guerra se acercaba a su fin, fue incluso haciéndose más fuerte.

Asimismo, mientras que, de acuerdo a la prensa de guerra, la situación que se vivía en los países aliados estaba marcada por la desunión entre los pueblos y sus gobiernos, de Paraguay, por el contrario, los periódicos resaltaban con grandilocuencia:

"En la América democrática no conocemos un pueblo más unido a su gobierno que el Paraguay. Al lado del gran mariscal López se ha levantado el pueblo para defender sus derechos, y en íntima y estrecha unión han formado el verdadero baluarte de la libertad, cuyo incontrastable poder y grandeza nace de esa unión que se consolida con el sacrificio común [...] Esta es la verdadera unión y la alianza más legitima que dignifica al pueblo soberano, y que hace superior a los gobiernos democráticos". ${ }^{30}$

${ }^{30}$ El Centinela, $\mathrm{n}^{\circ} 34,12 / 12 / 1867$, p. 1. 
Los artistas grabadores representaron esa desunión existente entre los aliados mostrándolos como un conjunto de hombres con rasgos étnicos diversos. De una manera muy compleja, esa heterogeneidad de los enemigos es la característica principal de los grabados que muestran a los soldados del bando contrario tanto en El Centinela como en Cabichui.$^{31}$ Por ejemplo, en un grabado de $E l$ Centinela donde se ve a los jefes militares aliados ante los leones paraguayos, dos de esos jefes aparecen representados con rostros de color negro. ${ }^{32}$ En otro grabado se muestra a soldados brasileños muriendo abrazados por las llamas de una hoguera; las étnias diferentes del grupo están marcadas por el contraste entre los colores blanco y negro usados en las figuras. ${ }^{33}$ Cabe aclarar que, de acuerdo a Thompson y Juan Crisóstomo Centurión, López en sus arengas a los soldados solía llamar "negros" indistintamente a los aliados. ${ }^{34}$

La antítesis entre luz y oscuridad, entre blanco y negro, puede ser interpretada como un símbolo del bien y el mal. La noción de luz como alegoría visible de lo bueno es importante dentro de la tradición cristiana. A su vez, el color de piel blanca se asoció a la civilización y al progreso de Paraguay, mientras que el color de piel negro fue ligado a la barbarie, al salvajismo y a la esclavitud del enemigo.

A pesar de que había negros luchando en el ejército paraguayo, gráficamente se utilizó siempre el blanco para representarlos. A comienzos de 1866, López había ordenado la emancipación de los esclavos con el fin de que engrosaran las filas del ejército. De esa manera se incorporaron al ejército paraguayo seis mil hombres que habían sido esclavos de las Estancias de la Patria. ${ }^{35}$ Incluso, uno de esos soldados alcanzó el rango de oficial. Thompson afirma que ese oficial fue enviado por el Mariscal a todos los combates, "hasta que fue muerto, librándose así [López] del oficial negro". ${ }^{36}$ De acuerdo a Jerry Conney es posible que en el ejército paraguayo hayan muerto proporcionalmente más soldados negros que otros, pues existen indicios de que López los mandaba a cumplir las misiones más peligrosas. ${ }^{37}$

${ }^{31}$ Luc Capdevila, "O gênero da nação nas gravuras da imprensa Paraguaia. Cabichuí e El Centinela, 1867-1868”: ArtCultura 9 (2007), p. 15.

${ }^{32}$ El Centinela, $\mathrm{n}^{\circ} 10,27 / 06 / 1867$, p. 3.

${ }^{33}$ El Centinela, $n^{\circ} 17,13 / 08 / 1867$, p. 3.

${ }^{34}$ George Thompson, La guerra del Paraguay (Buenos Aires 1910), p. 80; Juan Crisóstomo Centurión, Memorias o reminiscencias históricas sobre la Guerra del Paraguay, Tomo II (Asunción 1944), p. 28.

35 Josefina Plá, Hermano negro. La esclavitud en el Paraguay (Madrid 1972), pp. 163165.

36 Thompson, La guerra (nota 34), p. 83.

${ }^{37}$ Jerry W. Cooney, "La abolición de la esclavitud en Paraguay": Jerry W. Cooney/ Thomas Whigham, El Paraguay bajo los López. Algunos ensayos de historia social y política (Asunción 1994), pp. 25-38; Doratioto, Maldita guerra (nota 23), p. 220. 
Sin embargo, no es eso lo que reflejan los grabados que refieren al pueblo paraguayo, los que al resaltar una unidad étnica inexistente, manifiestan aquí, como en otras cuestiones, una representación compleja, basada en la omisión de la realidad, ya que el ejército de López estuvo formado por negros, mestizos, blancos e indígenas.

Luc Capdevila señala que los grabados de los periódicos paraguayos fueron dotados progresivamente de un poder de identificación en dirección a sus lectores, favoreciendo la complicidad entre movilizadores y movilizados. En el caso de El Centinela y Cabichuí, el sistema de oposición nosotros/ellos, traduce el enfrentamiento entre dos sistemas sociales: una Triple Alianza que reunía hombres desnaturalizados y heterogéneos, frente a un Paraguay homogéneo y unido, que marchaba en respuesta a la agresión de un conglomerado subhumano. ${ }^{38}$

En las imágenes, los soldados paraguayos aparecen con fisonomías y rasgos faciales idénticos, inclusive la semejanza se manifiesta en la contextura corporal. Si en los grabados se muestra una similitud física, en los textos se señala que esa similitud existe también en las "ideas", las "opiniones", las "voluntades" y los "sentimientos" ${ }^{39}$ Por ejemplo, bajo el título "El retrato de un soldado paraguayo", se afirma que "conocer uno, es el retrato de todos; y esa identidad de formas, de sentimientos y de convicciones dan la misma expresión y fisonomía a los soldados paraguayos; porque todos parecen gemelos". ${ }^{40}$

En los grabados, los rasgos de los soldados paraguayos siempre están bien definidos, mientras que los reclutas de los ejércitos de la Triple Alianza tienen rostros casi desdibujados. Con el epígrafe "Conducción de los batallones prisioneros de Tuyuty al Paso Pucú por una compañía de cazadores paraguayos", un grabado de El Centinela muestra a un grupo de soldados enemigos sin uniformes militares y con sus rostros negros, con rasgos faciales esbozados con círculos de color blanco. A esa ausencia de rasgos faciales definidos se suma la adjudicación de una contextura física diferente a cada uno de ellos. ${ }^{41}$

${ }^{38}$ Capdevila, "O gênero da nação" (nota 31), p. 17.

39 "Si examinamos el ESPIRITU PÚBLICO de este pueblo, solo encontraremos una opinión, una idea, un sentimiento y una voluntad”: El Centinela, nº32, 28/11/1867, p. 2.

${ }^{40}$ El Centinela, $\mathrm{n}^{\circ} 26,17 / 10 / 1867$, p. 2.

${ }^{41}$ En Cabichui los redactores expresaron en sus textos: "Qué diferente es la expresión del soldado de la libertad a la del esclavo en los peligros [...] Sus causas son conocidas: en el uno hay convicción, hay fe, hay constancia y resignación, que lo que defiende le inspira honor y gloria y que si sucumbe en su defensa, le esperan mayores y más positivos bienes en el goce de una felicidad sempiterna; y en el otro ¡todo es maldad, su corazón no siente esas dulces emociones de la virtud, sus ideas no están inspiradas sino de lo funesto y sombrío, que amortigua su espíritu y le hace ver en todo su perdición”. Cabichui, nº64, 12/12/1867, p. 2. 


\section{Imagen 5: "Conducción de los batallones prisioneros de Tuyuty al Paso Pucú por una compañía de cazadores paraguayos"}

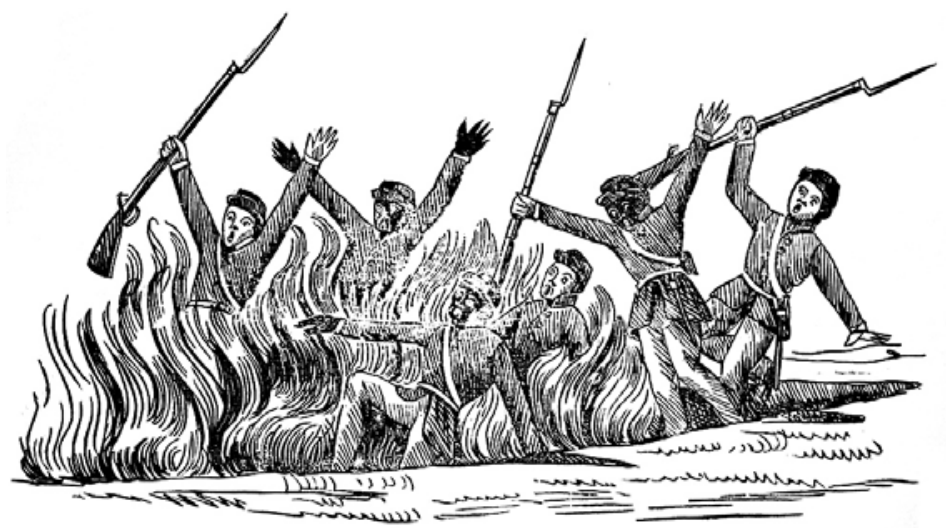

Fuente: El Centinela, n³2, 28/11/1867, p. 2.

Ante este grupo de soldados abatidos, los militares paraguayos montan guardia, orgullosamente armados y uniformados. En realidad, durante la guerra la escasez de ropa se hizo sentir con tanta fuerza entre los soldados paraguayos que se llegaron a aplicar medidas extremas como la de cortar las alfombras del Club Nacional y de la estación central del ferrocarril de Asunción para confeccionar ponchos con ellas. Con esos duros ponchos, señala Thompson, "los soldados parecían metidos entre dos tableros de fijar carteles" ${ }^{42}$ Asimismo, las prendas que se arrebataban a los muertos fueron consideradas un valioso botín y no fue extraño encontrar entre las tropas paraguayas a hombres vestidos con uniformes aliados. ${ }^{43}$

\section{Conclusiones}

En una coyuntura en la que fue necesario militarizar a la población para garantizar la defensa nacional, las autoridades otorgaron una particular importancia a los periódicos porque entendieron que a través de ellos podían condicionar las conductas y modelar las representaciones. Desde el rol propagandístico en el que el gobierno la posicionó, el fin de la prensa fue explicar la justicia de la causa paraguaya y convencer a sus lectores y oyentes de que debían luchar hasta "vencer o morir".

\footnotetext{
${ }^{42}$ Thompson, La guerra (nota 34), p. 137.

${ }^{43}$ Ibídem, p. 120.
} 
Esa propaganda difundida por los periódicos de guerra no irrumpió ya acabada sino que fue elaborándose en el devenir de la producción periodística, que eliminando ambigüedades se ocupó de crear un mensaje unívoco sobre las causas, características y consecuencias de la contienda. La prensa tuvo que articular un discurso que sirviera no solo para afianzar la moral de los soldados mientras los adoctrinaba, sino también para construir una identidad nacional que fortaleciera la unidad social. Con esos propósitos se vehiculizó un discurso de movilización que reposó en un sistema de oposición nosotros/ellos, que se plasmó a través del contraste entre representaciones negativas asignadas a los aliados y representaciones positivas atribuidas a los paraguayos y a su Mariscal.

Si bien los periódicos lograron sincronizar, bajo el seguimiento represivo del gobierno, un discurso de movilización homogéneo que confinaba al receptor en una interpretación unidireccional, el sistema de oposición en que basaron su prédica los condujo a la emisión de mensajes contradictorios: frente a los soldados brasileños, representados como esclavos obligados a luchar por un monarca déspota, los paraguayos se presentaron a sí mismos como ciudadanos libres y soberanos que peleaban por valores republicanos. Pero, en contraste, transmitieron al mismo tiempo una concepción paternalista del poder encarnado en López como padre irremplazable, merecedor de amor, veneración y obediencia. De esta manera, terminaron presentándose como hombres libres sin libertad por estar sujetos al autoritarismo de López, cuyo poder llegó incluso a legitimarse en la voluntad divina.

Concebidos como una continuación de la guerra a través de las palabras, el gobierno se preocupó de que los periódicos llegaran a todos y de que se impusiera la idea de que leerlos era expresión de lealtad a la causa paraguaya. La lectura pública de artículos con estructuras repetitivas y escritos en un español coloquial o en guaraní posibilitó que un mayor número de individuos tuviera acceso a la esfera de lo escrito, abriendo el camino para que lo impreso dejara sus huellas en una cultura fuertemente oral.

Los efectos de la contienda sobre la prensa y de esta sobre la propaganda del régimen de López llegaron más allá de los contenidos y de las tecnologías - que nacieron de la necesidad de suplir lo que el bloqueo aliado convertía en carestía - y terminaron produciendo cambios culturales de mayor alcance. Esos periódicos que surgieron con el fin de congregar a los paraguayos en torno a la figura del Mariscal, debieron transformarse para poder cumplir con ese objetivo. En ese proceso de cambio, la prensa brindó a la propaganda de López la posibilidad de enriquecerse y de constituirse en un legado consistente en una rica producción de textos en guaraní y de una xilografía con rasgos novedosos que es valorada como una de las manifestaciones más logradas del arte pictórico paraguayo. 